\title{
SANG KURIANG UTUY T. SONTANI DAN MITOSNYA DALAM PERSPEKTIF SASTRA BANDINGAN
}

\author{
THE KURIANG UTUY T. SONTANI \\ AND MYTH IN PERSPECTIVE OF COMPARATIVE LITERATURE
}

Yeni Mulyani Supriatin

Balai Bahasa Provinsi Jawa Barat, Jalan Sumbawa No. 11, Bandung

e-mail: yeni.mulyani@yahoo.com

\begin{abstract}
Abstrak
Sang Kuriang karya Utuy Tatang Sontani dipandang sebagai drama fenomenal dalam sejarah sastra drama Sunda. Drama yang ditransformasi dari legenda Sangkuriang itu dikritisi sebagai drama yang paling inovatif jika dibandingkan dengan Sangkuriang pengarang lain. Artikel ini bertujuan menggali dan menelusuri makna drama Sang Kuriang karya Utuy Tatang Sontani dalam perspektif sastra bandingan. Topik utama dalam artikel ini berkaitan dengan pemikiran Sang Kuriang dengan mengangkat beberapa masalah (1) bagaimana pemikiran Sang Kuriang dalam menghadapi ketidakadilan? (2) bagaimana makna drama Sang Kuriang jika dibandingkan dengan mitosnya? Metode penelitian menerapkan teknik penelitian perbandingan. Hasil penelitian menunjukkan bahwa Utuy dalam drama Sang Kuriang telah berhasil "menghidupkan" kembali tokoh lama, Sang Kuriang yang telah menjiwainya dengan pikiran dan paham baru. Sang Kuriang karya Utuy tampil dengan versi dan makna baru yang berbeda dengan mitosnya. Sang Kuriang, drama dalam bentuk libretto karya Utuy Tatang Sontani dalam khazanah sastra drama Sunda ditempatkan sebagai drama Sunda pascakemerdekaan.
\end{abstract}

Kata kunci: mitos, Sangkuriang, drama libretto, sastra bandingan.

\begin{abstract}
The Kuriang works Utuy Tatang Sontani regarded as phenomenal drama in the history of Sundanese literature. The Drama which transformed from the Sangkuriang legend, was criticized as the most innovative drama than other Sangkuriang author. This article aims to explore and discover the meaning of the Kuriang drama works Utuy Tatang Sontani in the perspective of comparative literatur. The main topic in this article related to the Kuriang's thought to raise the issue of (1) how the Kuriang thinking in the face of injustice? (2) how to play the Kuriang significance when compared to the myth? This research used the techniques of comparative research. The results showed that the Kuriang Utuy drama has managed to "revive" the old figure back, the Kuriang that has been animating with new thoughts and understanding. The Kuriang Utuy works performed with the new versions and different meanings to the myth. Utuy Tatang Sontani's works, The Kuriang drama in the form of the libretto was the literary treasures of drama Sundanese post-independence .
\end{abstract}

Keywords: myths, Sangkuriang, the drama libretto, comparative literature. 


\section{A. PEN DAHUluAN}

Sangkuriang telah melegenda, bahkan dianggap suci dan benar-benar ada serta dipandang penting keberadaannya dalam literatur khazanah sastra Sunda. Mengapa? Jawaban pertanyaan tersebut bisa bermacam-macam bergantung pada ancangan dan pandangan pikiran masingmasing. Sangkuriang dipandang penting, misalnya karena keberadaan Gunung Tangkuban Perahu yang berkaitan dengan alur kisah ini yang lokasinya berada di wilayah Jawa Barat. Hal penting lain mungkin saja pesan moralitas yang terkandung di dalam kisah ini yang tidak jauh berbeda dengan Lutung Kasarung, sama-sama mengungkapkan kisah anak lelaki yang mencintai ibunya, merupakan sesuatu hal yang dilarang dan tidak boleh terjadi. Untuk mencegah pernikahan terlarang, Guru Minda dihukum turun ke bumi dalam wujud lutung, sedangkan Sangkuriang diharuskan membendung Citarum dan membuat perahu dalam waktu semalam.

Kisah seorang anak lelaki mencintai ibunya lazim disebut dengan motif oedipus. Berancang-ancang dari kisah oedipus inilah, Utuy T. Sontani menafsir ulang dan mentrasformasikan legenda Sunda itu ke dalam bentuk libretto lakon Sunda dua babak dalam judul Sang Kuriang. Sebagai seniman modern, hal pertama yang menarik perhatian Utuy adalah mengubah penulisan nama protagonis lakon sekaligus yang menjadi judul kisah ini yang dalam mitosnya tertulis Sangkuriang menjadi Sang Kuriang. Perubahan tersebut ditafsirkan beberapa pakar sebagai pelegitimasian Sang Kuriang yang berasal turunan para dewa. Selain itu, penulisan Sang Kuriang seolah menegaskan bahwa Sang Kuriang berposisi sebagai pusat atas kekuasaan dan menunjukkan kedudukan yang sama dengan titisan dewa, sedangkan penciptanya menerangkan bahwa Sang Kuriang sebenarnya adalah Sang Guriang yang artinya makhluk turunan dewa.
Kisah tentang seorang anak yang jatuh cinta pada ibunya sesungguhnya tidak diketahui sejak kapan bermula, tetapi menurut Utuy hampir di setiap daerah di Jawa Barat memiliki versinya. Para pengamat sastra Sunda mengatakan bahwa libretto Sang Kuriang karya Utuy merupakan kisah yang paling inovatif yang berbeda dengan Sangkuriang karya penulis lain, seperti Sangkuriang Kesiangan karya Ajip Rosidi terbit pada tahun 1961 atau Sangkuriang versi Darmawidjaja pada tahun 1942.

Karya Utuy ini adalah suatu gubahan bebas yang berangkat dari legenda Sangkuriang, suatu mitos yang hampir dianggap benar-benar terjadi karena meninggalkan bekas yang menurut dugaan orang memang ada. Menurut mitosnya, dataran Bandung yang ada sekarang dilindungi oleh gunung dan bukit dari empat penjuru, bekas dasar sebuah telaga raksasa yang semula disiapkan oleh Sangkuriang untuk memenuhi permintaan Dayang Sumbi. Dapat dikatakan bahwa drama Utuy sejak pementasannya yang pertama mendapat sambutan di manamana. Pada tahun 2013 (tahun 2000-an) karya tersebut masih dikenang orang sebagaimana yang terapresiasikan dalam pementasan drama Sang Kuriang karya Utuy tanggal 1-3 Februari 2013 di Taman Ismail Marzuki.

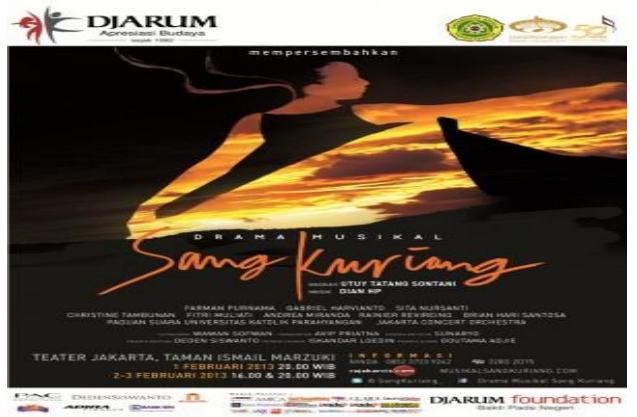

Gambar 1. Sang Kuriang Karya Utuy T. Sontani

di Taman Ismail Marzuki

Sumber: Yeni Mulyani Supriatin

Utuy Tatang Sontani di mata Rosidi (Kompas, 1972) adalah seorang pengarang sastra drama Indonesia dan Sunda 
terpenting. Namanya terangkat oleh roman Tambera (1948), tetapi ia lebih dikenal sebagai pengarang drama. Dramadramanya mengedepankan individualitas, seperti terekspresikan dalam Sayang Ada Orang Lain yang menampilkan tragedi yang terjadi karena adanya campur tangan orang lain ke dalam kehidupan rumah tangga seseorang. Puncak individualitas Utuy tampak gamblang dalam drama Sang Kuriang. Drama dalam bentuk libretto tersebut atau dalam istilah bahasa Sunda disebut gending karesmen yang ditransformasikan dari mitologi Sunda. Sang Kuriang di tangan Utuy menjadi sesuatu yang baru karena mendapat tafsir baru pula.

Sementara itu, Teeuw dalam Rampan (1980:176) menyebut Utuy sebagai seorang di antara para penulis yang paling produktif, setidaknya dalam tahuntahun pertama sesudah perang. Selain itu, karya Utuy bisa dianggap pantas diperhatikan karena berbagai alasan. Ditinjau dari segi teknis dan stilistik, ia merupakan pengarang yang paling mahir di antara pengarang seangkatannya. Ia mempunyai perasaan yang sangat tajam terhadap proporsi dan berhasil mencengkeram perhatian pembaca lewat variasi, kontras, bahasanya hidup, dan menarik. Meskipun beraneka ragam pokok cerita dan motifnya, karya Sontani dijelujuri jalur tema yang jelas. Ia selalu mempunyai keprihatinan terhadap orangorang sial, korban masyarakat, rakyat yang menentang ketidakadilan, kepalsuan, dan kesuksesan lahiriah, orang-orang yang mencari manusia sejati, dan manusia bebas yang berusaha menjadi dirinya dalam dunia yang memberinya peranan-peranan palsu.

Menggali makna karya drama libretto yang diciptakan lima dasawarsa yang lampau bukanlah sesuatu yang mudah.Tuntutan menampilkan kembali Sang Kuriang sebagai drama yang berbeda dengan mitosnya dan berbeda pula dengan yang ditulis oleh pengarang lain serta tidak stereotipe dengan drama sezamannya yang sarat dengan potret manusia korban perang, merupakan sesuatu yang menarik.

Landasan utama tulisan ini sematamata naskah Sang Kuriang ditunjang dengan teks Sang Kuriang-Dayang Sumbi karya Utuy Tatang Sontani tanpa mempertimbangkan bagaimana naskah itu diangkat ke dalam pertunjukan meskipun akan diulas sepintas berdasarkan apresiasi beberapa penulis yang menonton pertunjukannya.

Tulisan ini menggali makna yang terkandung dalam perilaku tokoh utama, yaitu Sang Kuriang dan Dayang Sumbi. Topik pembicaraan berkaitan dengan masalah pemikiran Sang Kuriang, bagaimana pemikiran Sang Kuriang dalam menghadapi ketidakdilan bahwa seorang perempuan cantik sebagaimana Dayang Sumbi bersuamikan si Tumang, makhluk hina bisa melahirkan seorang anak yang cakap dan gagah. Ketidakpercayaan Sang Kuriang terhadap keabadian fisik Dayang Sumbi yang tetap cantik menarik yang mengakui sebagai ibunya yang dikontraskan dengan kelogikaan, dan kebebasan atas kuasa sendiri.

\section{B. METODE PENELITIAN}

Karena tulisan ini menggali makna Sang Kuriang karya Utuy T. Sontani yang bersumber dari mitos Sangkuriang, metode penelitian menerapkan teknik penelitian perbandingan yang akan menjajarkan drama Utuy dengan mitosnya sehingga tampak persamaan dan perbedaannya. Dalam membandingkan Sang Kuriang karya Utuy dengan mitosnya, tulisan ini lebih menekankan pada upaya pencarian perbedaan di antara keduanya. Hal itu sejalan dengan pendapat Faruk (2008:2) bahwa metode perbandingan dalam ilmu bahasa, sastra, dan budaya cenderung mengarahkan perhatiannya pada penemuan persamaan. Untuk memperoleh pemahaman mengenai makna suatu karya, perbandingan selayaknya dibalik, yaitu pada upaya menemukan perbedaan dari objek yang dibandingkan. Hanya dengan kesadaran perbedaanlah toleransi, 
hubungan, dan makna suatu karya dapat dibangun.

\section{HASIL DAN BAHASAN \\ 1. Sang Kuriang dan Mitosnya}

Pengarang sastra drama Sunda pascakemerdekaan lebih memilih akar tradisi mereka sebagai sumber penciptaan dalam karya-karyanya. Akar tradisi masyarakat Sunda, antara lain adalah dongeng Si Kabayan, Sangkuriang, dan cerita pantun Sunda (Mundinglaya, Lutung Kasarung, Sulanjana), cerita anak-anak (Si Leungli, Geber-Geber Hihid Aing, Sakadang Tenggek, serta cerita sejarah, (sempalan Babad Cikundul, Dur Mangkur Dipati Ukur, dan Pangeran Jayakarta).

Utuy dalam "Sangkuriang Dayang Sumbi" yang dipublikasikan oleh Warga (1954, No. 96, 97, dan 98) membagi struktur kisah ke dalam tiga bagian, sedangkan Sang Kuriang terbitan Bhratara (1962) dan Balai Pustaka (1966) mengalurkan struktur lakon ke dalam dua babak. Utuy sengaja menyiapkan naskah sebagai bahan pertunjukan mengingat drama adalah bentuk karya sastra yang berpretensi dipentaskan.

$\begin{array}{ccc}\text { Sang } & \text { Kuriang diawali dengan } \\ \text { kegelisahan } & \text { Dayang } & \text { Sumbi yang }\end{array}$ diekspresikan melalui sikapnya yang sering melamun sejak kedatangan seorang jejaka gagah. Naluri seorang ibu begitu tajam, Dayang Sumbi yang mengusir Sang Kuriang karena telah membunuh si Tumang merasa bahwa jejaka yang kerap mengunjunginya itu adalah anaknya.

Deskripsi awal tersebut mengimplikasikan bahwa Sang Kuriang karya Utuy dimulai dengan kisah Dayang Sumbi yang sudah mempunyai anak lelaki bernama Sang Kuriang.

Drama Sang Kuriang karya Utuy tersebut jika dibandingkan dengan mitosnya, bagian awalnya cukup berbeda. Legenda Sangkuriang dimulai dari kisah asal-usul Dayang Sumbi. Raja Sungging Perbangkara yang sedang berburu di hutan buang air seni yang tertampung dalam daun cariang. Seokor babi hutan bernama
Wayungyang yang tengah bertapa meminum air seni itu. Wayungyang hamil dan melahirkan seorang bayi cantik. Bayi cantik itu dibawa ke keraton lalu diberi nama Dayang Sumbi. Setelah tumbuh menjadi seorang gadis, banyak raja yang ingin meminangnya, tetapi tidak seorang pun diterima. Kemudian, atas permintaan sendiri, Dayang Sumbi mengasingkan diri di sebuah bukit ditemani seekor anjing jantan, si Tumang. Ketika asyik menenun, teropong yang digunakan menenun jatuh. Dayang Sumbi berjanji siapa pun yang mengambilkan teropong apabila laki-laki akan dijadikan suami. Si Tumang mengambil teropong, diberikannya pada Dayang Sumbi. Dayang Sumbi menikah dengan Tumang dan melahirkan bayi tampan diberi nama Sangkuriang.

Dengan demikian, Utuy dalam Sang Kuriang tidak mempersoalkan asal-usul Dayang Sumbi dan Sang Kuriang sehingga pembaca yang tidak mengetahui mitos Sangkuriang dapat dipastikan buta terhadap latar belakang keduanya, sedangkan dalam mitosnya dijelaskan bagaimana sejarah Dayang Sumbi dan Sangkuriang lahir ke dunia.

Drama karya Utuy episode berikutnya menggambarkan keadaan Sang Kuriang yang tidak tenang karena di dalam lubuk hatinya menyembunyikan keingintahuan asal-usul dirinya dan siapa ayahnya? Ibunya menjawab bahwa ayah Sang Kuriang adalah si Tumang yang selalu menemaninya. Sang Kuriang tidak bisa menerima kenyataan bahwa ayahnya adalah si Tumang, manusia bisu dan berasal dari masyarakat kelas bawah, sedangkan ibunya berasal dari masyarakat kelas atas. Oleh karena itu, Sang Kuriang sangat membenci si Tumang. Ketika si Tumang mendekati Sang Kuriang dan memeluknya, Sang Kuriang mengancam akan membunuhnya. $\mathrm{Si}$ Tumang mengabaikan ancaman itu. Sang Kuriang pun membunuh si Tumang.

Dalam drama Utuy diketahui bahwa si Tumang adalah seorang manusia berpenampilan buruk dan berasal dari 
rakyat jelata, sedangkan dalam mitosnya, si Tumang adalah seekor anjing. Hal itu mereprensentasikan bahwa sesungguhnya yang membedakan si Tumang dalam kedua karya itu hanyalah wujudnya, sedangkan peran dan fungsi si Tumang tetap sama, yaitu sebagai ayah Sang Kuriang dan selalu menemaninya yang mencerminkan kesetiaan.

Segmen berikutnya menggambarkan Sang Kuriang jatuh cinta kepada Dayang Sumbi. Dayang Sumbi menolak Sang Kuriang dengan alasan ia adalah ibunya. Sang Kuriang tidak memercayai perkataan Dayang Sumbi yang mengaku sebagai ibunya karena secara logika pengakuan itu tidak masuk akal. Setelah berpuluh-puluh tahun tidak bertemu, Sang Kuriang tidak mengenali lagi ibunya. Perempuan yang disukainya mustahil ibunya karena ia tampak muda dengan fisik yang segar tidaklah mungkin mempunyai anak sebesar dirinya. Alasan lain, Sang Kuriang meragukan pengakuan Dayang Sumbi karena tidak ada yang mengetahui bahwa Dayang Sumbi yang melahirkannya atau bukan. Sang Kuriang tetap ingin menikahi Dayang Sumbi. Ia lebih memercayai keyakinannya daripada perkataan orang lain. Dayang Sumbi mencari akal supaya pernikahan gagal. Karena terpaksa, ia mau dijadikan isteri, tetapi Sang Kuriang harus membendung Sungai Citarum dengan dalih sebagai tempat berlayar saat berbulan madu. Harus disiapkan pula perahu dan syarat lain pekerjaan itu harus selesai semalam, sebelum matahari terbit. Sang Kuriang menyanggupi permintaan itu. Sang Kuriang dapat memenuhi permintaan itu karena kesaktiannya dan pertolongan siluman. Namun, tipu muslihat ibunya yang memancangkan sehelai kain putih kasar di sebelah timur, bunyi lesung, dan ayam berkokok, mengesankan bahwa waktu menjelang pagi, menggagalkan pekerjaan Sang Kuriang. Telaga raksasa sudah jadi, tetapi perahu baru rangka.

\section{Sang Kuriang yang Kritis}

Resepsi Utuy terhadap mitos Sangkuriang merupakan transformasi lintas bentuk dari mitos lisan menjadi drama libretto yang khas dan berkarakter. Sangkuriang karya Sacadibrata pada akhir kisah menggambarkan Dayang Sumbi sedang dikejar-kejar oleh Sangkuriang lalu gaib di Gunung Putri, gunung itu sampai sekarang dinamai Gunung Putri, sedangkan Sangkuriang menerjunkan diri ke laut selatan mengikuti jejak Nyai Loro Kidul. Darmawidja menceritakan bahwa Sangkuriang ditelan air danau buatannya sendiri atas kutukan dewata yang memenuhi permintaan Dayang Sumbi dan Dayang Sumbi mengikuti Sangkuriang terjun ke dalam danau yang meluap-luap. Dalam mitosnya pun, akhir kisah Sangkuriang cukup beragam, antara lain ada yang mengisahkan bahwa Sangkuriang menendang perahu melesat jauh hingga tengkurap. Perahu dan tempat itu dikenal Tangkuban Perahu.

Sang Kuriang karya Utuy jika hendak dijajarkan dengan mitosnya atau Sangkuriang karya penulis lain memiliki perbedaan signifikan. Utuy dalam drama libretto Sang Kuriang hanya mengambil bagian akhir mitos, yaitu setelah Sang Kuriang berusia remaja. Menurut Sutiasumarga (1959: 2) pengembaraan Sangkuriang sebenarnya adalah pengembaraan pikiran yang akhirnya memuncak dalam kesepian atau kekosongan jiwa. Jadi, bukan benar-benar pengembaraan yang dilakukan oleh wujud lahiriah (badani). Kesepian atau kekosongan jiwa terefleksikan sebelum dan setelah Sang Kuriang mengetahui bahwa ayahnya adalah si Tumang. Sebelum mengetahui siapa ayahnya, Sang Kuriang bertanya-tanya dalam hati bahwa setiap manusia pasti sama, yaitu lahir ke dunia beribu dan berbapak, sedangkan ia hanya beribu, mana bapak? Pikiran semacam itu dipandang sebagai anak yang kritis dan cerdas. Yang selalu menemani Sang Kuriang adalah si Tumang, lelaki bungkuk dan buruk rupa. Kekritisan Sang 
Kuriang itu tampak saat dia bertanya pada ibunya,

Sang Kuriang: Mun lain kudu ka leuweung, ka mana nya kudu lunta? Campur jeung pada manusa, Kuring sok loba nalangsa.

Dayang Sumbi: Anaking, anak sahiji, naon nu jadi nalangsa?

Sang Kuriang: Ibu, mungguh nu kangaranan manusia, sok puguh indung bapana, ngan kuring sorangan bae kasebut medal ti indung, tapi teu nyaho di bapa. Mun aya saha ngaranna, Di mana tempat matuhna? Tapi unggal ditanyakeun, Ibu sok tara nerangkeun. Nalengteng $k a$ deungeun-deungeun, Jawabna: Nyaho ti mana, da horeng taya nu terang, iraha kuring gumelar, lamun terus kaya kieu, di mana-mana parireu, keur naon rumingkang oge, leuwih hade paeh bae

Dayang Sumbi: Deudeuh teuing anak ibu, horeng inya gering pikir, seug ibu arek balaka, wakca mo ngilungan deui, tapi ujang ulah rentang, ulah rek gedag $k u$ angin, mangka eling yen enggoning urang hirup, urang hente wasa, darma wawayangan bae, dipolahkeun ku kersana nu Kawasa, ku kituna, mun dina lalakon indung, aya kahelokan, omat Ujang ulah silo, masing awas ka nu ngahelokeunana.

Sang Kuriang: Kahelokan naon tea, anu tumiba ka ibu, ku kersana nu Kawasa?

Dayang Sumbi: Hiji mangsa waktu ibu jongjon ninun, di nu nyingkur sepi jempling, ujug-ujug datang lesu, ilang daya leungit aji, taropong ragrag $\mathrm{ka}$ kolong, pasrah sadrah ka anu ngersakeun lesu, nu wenang beurang jeung peuting, Ibu nya pok ragrag ku pameuli, ka nu ngasongkeun taropong. mun lalaki, kajeung saha bakal diaku salaki, mun awewe, kajeun saha, diaku dulur sapetna. Teu lila aya lalaki, datang ngasongkeun taropong, ditilik diawas-awas, sihoreng nu nurut hirup, nu ngingiclik ngabadega, bakat reuwas ibu tuluy kapiuhan, teu inget di beurang peuting, teu nyaho ka naonkaon, tapi ti sanggeusna kitu, awak ibu jadi salin, heunteu lila ti harita, nya terus ujang gumelar.
Sang Kuriang: Euleuh-euleuh hente sangka, aya dongeng bet matak helok teuing, kutan teh nu jadi indung digadabah badega, boga bapa horeng alatan teu puguh, eta badega nu ngan sakadar jadi lantaran kuring gumelar, naha aya naha euweuh? Mun aya di mana tempat matuhna, mun euweuh di mana kuburanana

Dayang Sumbi: Seug ku ibu dituduhkeun, tapi ujang ulah poho enggoning nenjo ka batur, omat ulah mandang lahir, silo serab ku rupana, sabab mungguh nu kumelip, kabeh ge wujud nu Nyipta, nu ngageugeuh dina jirim

Sang Kuriang: Eta badega nu jirimna kageugeuhan kunu nyipta, ayana di mana? Dayang Sumbi: Mun Ujang malik ka tukang, Ujang tanwande patepang

Sang Kuriang: Euleuh ieu! Sihoreng si Tumang! Badega ge pireu, nya bongkok, nya pincang, aduh, ibu, kuring teu kaduga teuing, nandangan coboba, naha dewata ka kuring, teungteuingeun luluasan, ngajangjawing lieuk deungeun lieuk lain, Natanyakeun bapa, Ari ayeuna geus panggih, geuning bet kieu rasana. (Sontani, hlm.14-18)

Sang Kuriang: Kalau bukan rimba, dimanakah tempat hamba? Bergaul dengan sesama manusia, hamba merasa jadi makhluk celaka.

Dayang Sumbi: Tuan anak ibu yang dicinta, tiada alasan merasa celaka

Sang Kuriang: Ibu, semua manusia yang bernama manusia, lahir ke dunia ada beribu ada berbapak, hanya hamba seorang, lahir dari kandungan ibunda dengan tak tahu siapa bapak. Sudah berulang-ulang hamba bertanya: siapa gerangan bapak hamba, dimana gerangan dia berada? Tapi ibunda selalu berahasia, sedang orang lain selain bunda, kalau ditanya, selalu menjawab sama: "Bagaimana kami tahu? Lahirmu kami tak tahu!"

Dayang Sumbi: Wahai, kasihan anakku sayang! Baiklah mulai sekarang ibu berterus terang. Sebelumnya, dengar! kebenaran yang menjadi darah daging ibu 
dan jadi darah dagingmu pula. Bahwasanya segala peristiwa yang terjadi atas diri manusia adalah kehendak dewata raya. Manusia tiada daya upaya karena ada yang menggerakkan. Apabila ibu dahulu mengalami keajaiban, jangan tuan membatasi pandangan kepada bunda, tapi memandanglah kepada dewata yang kuasa menggerakkan segala atas mau-Nya.

Sang Kuriang: Keajaiban apakah gerangan yang telah bunda alami, atas kehendak dewata yang menggerakkan?

Dayang Sumbi: Dahulu di siang hari yang sangat panas, dikala bunda seorang diri, menenun di sana di tempat sepi, tiba-tiba diserang lesu yang sangat hebat sehingga terlena tiada berdaya setelah taropong jatuh ke kolong. Berkatalah bunda tuan: barangsiapa suka menolong mengambil taropong dari kolong dia akan kawan sekiranya perempuan; dia akan jadi suami sekiranya laki-laki. Dengan tak disangkasangka muncul budak lelaki mengunjukkan taropong dan bunda yang tak berdaya, terkejut lalu terlupa, tidak sadar biar. Semenjak itu merasa bahwa bunda berbadan dua. Sembilan bulan kemudian tuan pun lahir.

Sang Kuriang: Wahai, suatu keajaiban luar biasa! Hampir tidak percaya hamba mendengarnya. Kalau begitu hamba lahir ke dunia berbapakan hanya seorang budak.

Dayang Sumbi: Ketahuilah bahwa yang menjadi bapak sekadar jadi lantaran supaya bunda mengandung tuan atas kehendak dewata.

Sang Kuriang: Dimanakah itu budak yang hanya sekadar jadi lantaran? Sudah matikah dia, atau masih hidup gelandangan?

Dayang Sumbi: Bunda mau tunjukkan, tapi sebelumnya dengarlah pesan: dalam memandang kehidupan jangan tuan disilaukan penglihatan; dalam menilai manusia jangan hanya terbatas pada lahirnya. Memandanglah pada dewata yang selalu ada di mana-mana, ada di balik segala makhluk yang berlainan di dalam bentuk.
Sang Kuriang: Jadi di manakah dia, itu dewata berbentuk budak?

Dayang Sumbi: Kalau tuan sekarang berpaling ke belakang, sekaligus tuan akan berhadapan dengan bentuk yang ditanyakan.

Sang Kuriang: wahai, ini si Tumang! Budak bisu, bungkuk, pincang! Duh, ibu alangkah pedih rasanya hati, merasakan kenyataan sepahit ini. Mengapa hamba dan bukan orang lain yang diturunkan dewata secara main? Sebelum tahu siapa bapak, hamba selalu menjauhi orang banyak. Dan sekarang setelah mengetahui hidup hamba akan terasa bertambah sunyi.

Dialog antara Sang Kuriang dan Dayang Sumbi dalam penggalan drama Sang Kuriang menggambarkan beberapa hal penting. (1) mencerminkan Sang Kuriang yang berpikir kritis. Ia kritis melihat realitas bahwa setiap anak lahir ke dunia pasti memiliki ayah dan ibu, sedangkan ia hanya memiliki ibu, (2) Sang Kuriang mengetahui latar belakang ibunya, mengapa menikah dengan si Tumang, dan (3) Sang Kuriang tidak menerima bahwa si Tumang yang selama ini menjaga dan menemaninya adalah ayahnya. Kekritisan Sang Kuriang juga tampak dari cara berpikirnya yang mampu menganalisis latar belakang lahirnya ke dunia. Yang disesalkannya mengapa harus melalui si Tumang, orang yang sangat hina? Sangat timpang perempuan cantik, menarik, dan menawan dipasangkan dengan si Tumang yang buruk rupa, rendah, dan jijik. Sang Kuriang dapat menerima nasib ini jika itu kehendak dewata. Namun, keberterimaan itu membawa efek lain pada sikap Sang Kuriang, yaitu ia sampai pada simpulan bahwa kekeruhan dan ketidakadilan itu sudah dimulai oleh dewata yang menjadikan manusia, mengapa manusia pula harus bersih? Ketidakadilan, ketidakpercayaan, dan ketidakpantasan seorang lelaki cacat dan buruk rupa adalah ayahnya dan sesuatu yang tidak adil adalah Dayang Sumbi yang cantik dihamili oleh si Tumang, yang hina seperti anjing. Sang Kuriang dengan penuh kesadaran 
membunuh si Tumang sebagai bentuk protes terhadap dewata yang telah menciptakan ketidakadilan. Dengan kata lain, alasan utama Sang Kuriang membunuh si Tumang dan melamar Dayang Sumbi karena tidak menganggap adanya wujud ibu dan bapak yang memperlihatkan gambar ketidakadilan. Peristiwa yang menggambarkan Sang Kuriang membunuh si Tumang terbaca dalam kutipan berikut.

Sang Kuriang: Ceunah kersaning dewata, ceunah manusa teu wasa, pangna aya kahelokan, nu tumiba ka manusa, pangna ngindung kanu geulis, dibapaan ku rurujit, nu puguh kalah cangcaya: Boa heueuh biheung bohong, indung sakitu dontona, asa piraku, geus dipurak ku badega, nya goreng patut nya tanpadaksa, tapi di enyana bohong, di heueuhna kahelokan, ka saha kudu tatanya, iwal ti ngan ka si Tumang, mahluk pireu teu nyowara, ngajentul teu samanea. Tumang! Aing ka sia jadi cangcaya, saha sia jadi nyiksa, di enyana sia bapa, sia keur aing ngerakeun, jadi beungbeurat saumur-umur, Tumang! Aing nyao teuing, saha sia saeunyana, nu geus sidik lain boa, sia teh ku goreng patut, ari itu Dayang Sumbi, geulisna ka bina-bina. Si Tumang rek ngarangkul.

Aeh, sia rek ngarangkul, boga angkeuh jadi bapa? Tapi aing teu rek sudi, teu arek nalian maneh, geus seubeuh aing disiksa, ku tatanya ka nu lian, ayeuna kudu ditambah, ku ngaheueuhkeun ka deungeun, magar sia bapa aing? Teu, aing teu arek sudi, teu rek nyanghulu ka batur, ceunah sia, ngaku jadi nu ngayuga, kuma karep kuma dinya. Tapi aing, ngan rek heueuh $\mathrm{ka}$ ceuk aing: Ti mana nya asal aing, eta aing nyao teuing, ku kituna, Lamun sia jeung enyana, ngaku jadi nu ngayuga, eta hartina: Hiji ti antara dua, naha aing naha sia, nu kudu musna di dunya, sabab nu disebut bener, teu kaci leuwih ti hiji. Si Tumang ngarangkul. Aeh-aeh, sia wani rungkal-rangkul, melaan heueuh ceuk sia, lamun kitu, jadi kawajiban aing, ngabela heueuh ceuk aing, ku jalan ngeuweuhkeun sia (nubles) (Sontani, 1962, hlm.31-32).
Sang Kuriang: dikatakan segalanya kehendak dewata raya; disebutkan manusia tiada daya upaya; semuanya hendak menunjukkan keajaiban yang minta ditelan dengan kepercayaan, tapi yang nyata sekarang aku bertanya: tidak bohongkah ibuku bercerita? Ibuku yang sangat cantik, yang membuat aku jatuh cinta, benarkah dia pernah dipetik oleh si Tumang, makhluk jelek tanpa daksa?

Wahai, keajaiban atau kebohongan, itulah soal yang sekarang dihadapkan, tapi kepada siapa aku mesti bertanya, selain pada si Tumang yang bisu pula, yang sekarang berjongkok di hadapan justru sebagai makhluk yang meragukan?

Tumang! Siapa kau sangat kusangsikan. Dan jika benar kau bapakku, kau membuat aku malu. Akhirnya kau bagiku merupakan beban yang akan membuat kepalaku runduk tertunduk malu

Hai, engkau mau merangkul aku, lantaran mengaku jadi bapakku? Tidak! Pergilah kau jauh ke sana. Aku tak sudi lagi bertanya-tanya. Sudah cukup aku menderita disebabkan orang lain yang membisu tentang bapakku, sekarang ditambah pula orang lain yang mengatakan bahwa kau bapakku? Tidak! Mulai sekarang hanya aku dan bukan orang lain yang akan kujadikan peganganku.

Jikalau engkau berkeras juga, mengaku diri menjadi bapak, silakan itu adalah pengakuanmu. $\mathrm{Aku}$ hanya menunduki yang benar bagiku: aku tidak menyaksikan, siapa yang melahirkan. Jika engkau berkeras juga mengaku menjadi bapak, salah seorang dari kita harus mati demikianlah seharusnya, sebab kebenaran tidak mungkin ada dua. Kalau begitu, terimalah ini tikaman sebab kebenaranku pun wajib dipertahankan (menikam).

\section{N ilai Kepercayaan vs Logika}

Hal lain yang menarik dalam Sang Kuriang karya Utuy, dikemukakannya nilai kepercayaan yang dianut oleh masyarakat lebih tua. Nilai kepercayaan beroposisi dengan logika (berpikir). Nilai kepercayaan tetap dijunjung, sebaliknya 
nilai tersebut akan hilang jika yang harus dipercayai itu tidak sesuai dengan logika berpikir. Dayang Sumbi yang mewakili masyarakat lebih tua menjunjung nilai kepercayaan. Sang Kuriang harus percaya bahwa si Tumang yang dibunuhnya adalah ayah kandungnya. Sang Kuriang menerima keterangan ibunya dengan pasrah. Itu yang terjadi dalam mitos Sangkuriang.

Dalam drama karya Utuy, Sang Kuriang tidak percaya bahwa si Tumang adalah ayahnya. Ketidakpercayaan Sang Kuriang berlandaskan pada logika berpikir bahwa sesuatu yang tidak masuk akal, si Tumang yang dinilainya sebagai orang berkelas rendah, cacat, dan buruk rupa bisa menikah dengan Dayang Sumbi yang cantik jelita dan berasal dari kasta bangsawan.

Sang Kuriang juga tidak percaya bahwa Dayang Sumbi adalah ibunya. Menurut logika Sang Kuriang, ia tidak mengetahui atau mendengar bahwa Dayang Sumbi pernah mengandung dan juga melahirkannya. Dalam hal ini, Sang Kuriang hanya menganut paham kepercayaan sendiri karena tidak ada orang lain yang menurutnya bisa menjawab pertanyaannya, sebagaimana terbaca dalam kutipan berikut.

Lamun kieu galagatna: Itu ieu henteu wasa, itu ieu ukur darma, parireu di mana-mana, taya deui jalan sejen, iwal ti kudu nalengtengna ka awak sorangan, ngaheueuhkeun $k a$ sorangan, tapi mun aing nanya ka aing, jawabna: nyaho teh teuing, heueuh aing ka ceuk aing, nya heueuh ka nyao teuing! Kumaha aing rek nyaho, da teu nyaho di wiwitan, teu nyaho ti saha asal, magar indung kungsi ngandung, eta ge nyao teh teuing, teu nyaho ka nu teu nyaho, nyaho soteh $\mathrm{ka} n u$ nyaho, nya ieu jawab ti aing, nya ieu nu saheueuhna, nya ku kieu aing punah, teu arek tatanya deui. (Sontani, 1962:29)

'Kalau semua orang membisu lantaran bisu dan tidak tahu, hanya pada diri sendiri aku leluasa bertanya-tanya. Dan jawaban dari diri sendiri, itulah kebenaran satu-satunya. Jawabannya: tidak tahu. Kalau begitu, ketidaktahuan itulah satu-satunya kebenaran. Sesungguhnya, aku tidak mengetahui dari mana aku datang, siapa yang menyebabkan, sejak kapan dikandung ibu bahkan aku tidak tahu dengan pasti bahwa aku pernah datang dari perut perempuan yang kini mengaku ibu'.

Seandainya mengakui ibu pada Dayang Sumbi dan bapak pada si Tumang, Sang Kuriang selamanya merasa tersiksa lahir batin karena ada ketidakadilan. Satusatunya jalan agar terlepas dari siksaan, Sang Kuriang harus mempunyai pikiran tidak mengakui ayah-ibu yang diwujudkan oleh Dayang Sumbi dan si Tumang. Sang Kuriang bukan manusia "kosong" bukan pula tanpa prinsip yang kuat dan berani tidak mengakui ibu-ayah, melainkan memiliki pegangan lain sebagai gantinya, yaitu ia mempunyai "aku" ego keakuan yang kuat yang menjadi dasar semua putusannya. Si Tumang dibunuh, dimaknai sama dengan membunuh kenyataan yang menyiksanya. Lamarannya pada Dayang Sumbi mengimplikasikan niatnya yang ingin membangun kehidupan baru yang di dalamnya mengandung "aku" serta terbebas dari siksaan. Kita simak kutipan dialog Sang Kuriang dan Dayang Sumbi yang mengekspresikan perbedaan pikiran Sang Kuriang dan pikiran Dayang Sumbi Sang Kuriang: Teu kurang teu kacopelan, henteu geuneuk teu maleukmeuk, ku tina caang-caangna,breh heueuh saheueuhna, sihorenag taya nu enya, bapa ceunah indung ceunah, ceunah ceuk boa, ceunah ceuk biheung.

Dayang Sumbi: Bapa cenah indung cenah? Heureuy teh bet kaleuwihan, ka mana ari si Tumang, ka Ujang henteu maturan?

Sang Kuriang: Si Tumang mutuh mantangul, teu kalis ku disisia, keukeuh hayang dipiheuueh, ngaku-ngaku magar bapa, ku tina keukeuh peuteukeuh, nya kapaksa ditelasan

Dayang Sumbi: Sang Kuriang! $\mathrm{Na}$ teu teurang, yen peta kitu lakuning jalma nu silo? 
Sang Kuriang: Teu pisan rumasa silo, teu pisan rumasa lolong, da ti bareto ge awas, ka nu donto, nu ayeuna aya di hareupeun pisan.

Dayang Sumbi: Sang Kuriang!

Sang Kuriang: disaparahyangan, tetela geus lain boa, mo aya nu nanding geulis, ka nu donto, nu ayeuna aya di hareupen pisan, eta nu donto, kersa teu kersa ayeuna rek ditanyaan ku kakang rek dipigarwa

Dayang Sumbi: Sang Kuriang. Boa andika kasarumahan, hayang migarwa indung sorangan.

Sang Kuriang: Na ceuk saha, nu geulis kungsi ngakandung kakang? Na ceuk saha nu donto kungsi medalkeun kakang?

Dayang Sumbi: Ceuk saha? Nya ceuk kula! Nya kula anu nyaksian andika medal ti kula! (Sontani, 1962:37-40)

Dayang Sumbi: Aku bukan ibunda? Ah, jangan tuan bercanda. Dimana pula si Tumang? Sendirian saja tuan pulang.

Sang Kuriang: Si Tumang keras kepala mengaku diri menjadi bapak; meskipun hamba menolak, namun dia malah bertindak. Akhirnya terpaksa dia ditikam dibunuh,itulah jalan yang mesti ditempuh.

Dayang Sumbi: Dibunuh? Ya, dewata! Di hadapanku berdiri anak durhaka, Sang Kuriang, tahukah bahwa tuan sudah melakukan perbuatan terkutuk, lantaran silau memandang bentuk?

Sang Kuriang: Hamba tidak silau tidak buta, sebenarnya sudah lama hamba merasa tertarik oleh wanita cantik yang sekarang ada di hadapan, berkilauan menggiurkan.

Dayang Sumbi: Sang Kuriang!

Sang Kuriang: Di seluruh Parahiangan, hamba tahu tiada perempuan yang lebih menarik dari wanita cantik yang sekarang ada di hadapan, berkilauan, menggiurkan.

Wanita cantik menarik tak mau dipinang, hamba pinang untuk dipetik!

Dayang Sumbi: Sang Kuriang! Tuan kemasukan berani meminang ibu yang melahirkan?

Sang Kuriang: Siapa yang menyaksikan bahwa tuan, ibuku yang melahirkan? Siapa yang menyaksikan bahwa hamba lahir dari kandungan tuan?

Dayang Sumbi: Siapa yang menyaksikan? Hamba! Hamba yang mengandung tuan, hambalah yang menyaksikan tuan lahir dari kandungan hamba.

Sang Kuriang yakin pada pendiriannya bahwa Dayang Sumbi bukanlah ibunya. Oleh karena itu, ia akan memperisteri Dayang Sumbi, istri yang akan mengurus anak-anaknya, sebagaimana terbaca dalam teks: $K u$ kituna, kersa teu kersa, nu geulis rek dipigarwa, dijieun indung nu estu, indung manusa nu bakal nu asal ti Sang Kuriang! (Sontani, 1962:40). 'Mau tidak mau yang cantik akan kuperisteri jadi ibu utama, ibu dari anak-anak yang bakal datang dari Sang Kuriang'

Dialog tersebut mengimplikasikan pertentangan yang mempertahankan kebenaran, kebenaran Sang Kuriang yang beroposisi dengan kebenaran Dayang Sumbi.

Jika tidak terlaksana dengan Dayang Sumbi, menurut logika berpikir Sang Kuriang hal itu berada di luar kekuasaannya sebagai manusia bukan karena Dayang Sumbi adalah ibunya. Penokohan Sang Kuriang benar-benar bersifat revolusioner, menggambarkan jalan pikiran yang merdeka dan memiliki pribadi yang kuat. Bagi Sang Kuriang yang dperjuangkan bukan hanya cintanya pada Dayang Sumbi, melainkan perjuangan manusia yang mendambakan keadilan, keselamatan, dan kebahagiaan.

\section{Menjunjung Individualitas}

Utuy dalam Sang Kuriang juga menginterpretasi mitos Sunda itu dengan memasukkan paham-paham baru tentang kebebasan manusia (Sutiasumarga, 1959:43). Kebebasan yang dimaksud bisa berarti kebebasan berpikir dan bertindak yang merupakan wujud individualitas. Utuy mengangkat Sang Kuriang yang berpikir setingkat Kirillof, tokoh penting dalam roman Dostojewski. Kirilloff memutuskan membunuh diri untuk 
membuktikan kemerdekaannya: bahwa hidup adalah miliknya. Sang Kuriang dan Dayang Sumbi bersama-sama mengusung kebebasan berpikir dan bertindak atas dasar keyakinan masing-masing. Kebebasan berpikir dan bertindak bisa terjadi dalam segala hal termasuk ke dalamnya bebas bertindak mengambil putusan mengakhiri hidup atas kuasa sendiri. Berikut sebuah kutipan yang diucapkan oleh siluman yang mendukung tindakan serta memberi pujian terhadap Sang Kuriang, satu-satunya makhluk yang paling berkuasa di jagat ini yang akan menyandingkan seorang perempuan seksi. Saha nu teu silo ka pageto, bakal nyandingkeun nu donto? Sang Kuriang! Saha manusia bebas merdeka, ngawangun sanggeus ngarakrak? Sang Kuriang! Saha manusa anu linuwih Umaku asal sakabeh? Sang Kuriang! Sang Kuriang! Taya dua di sajagat. (Sontani, 1962:61)

Sang Kuriang dalam pandangan mahkluk siluman adalah manusia bebas yang bisa berbuat apapun sesuai dengan kehendaknya. Bebas merdeka bisa mendua arah maknanya, pertama, Sang kuriang bebas berpikir sesuai logika akalnya, kedua, ia bebas bertindak sesuai dengan keinginannya. Semua terefleksikan saat Sang Kuriang melamar Dayang Sumbi dan membunuh dirinya karena tidak terlaksana memperisteri Dayang Sumbi.

Sesuatu yang tidak masuk akal perempuan dengan ciri-ciri fisik kemudaan mengaku ibu bagi seorang pemuda yang secara kasat mata tampak seusia dengan dirinya

"Heuheuy deuh, luyu! Sakitu campernikna ngabasakeun ibu ka nu sakieu jalugjug jangkungna. Saha nu ngabantah, nu ukal ekol neangan akal? Mangka kumpulkeun sakabeh manusa di ieu dunya. Mangka tanya hiji-hiji: naha asup kana akal, nyai anu sakitu sumedeng kumecrotna ngaku-ngaku anak ka jirim lalaki nu sakieu geus ranteng urat tarangna? Di ayana oge, indung kakang mah moal boa geus cetuk huis. Jeungna deui hamo rek aya di dieu, tapi tuh di ditu, di karaton nu salieuk beh, loba dahareun, loba titaheun" (Sontani, 1954:8).

Sang Kuriang tidak menerima penjelasan apa pun dari Dayang Sumbi. Ia mendesak dengan paksa memperisteri Dayang Sumbi. Dayang Sumbi angkat tangan. Ia pasrah menyerahkan pada takdir yang kuasa sambil berihktiar, berupaya mencegah agar pernikahan itu tidak terjadi, sebagaimana terbaca dalam kutipan berikut.

Dayang Sumbi: Takdir teu beunang dipungkir, kadar teu beunang disinglar, hade goreng geus papasten, pangasih ti nu kawasa, naon nu bakal tumiba, nya kuma kersa nu agung, kuring mah darma ikhtiar, teu rek nolak teu rek mundur, da puguh ka kulit daki, tapi wajib narekahan, ihtiar bari carincing, (Sontani, 1962:42)

Sang Kuriang harus membendung Sungai Citarum sampai menjadi sebuah telaga serta membuat perahu untuk bermulan madu dalam waktu semalam, sebagaimana terbaca dalam kutipan berikut.

Di nu anggang ka nu lian, di nu nyingkur taya batur, jauh ka papada jalma, nya dinu kitu, kula pasrah sadadaya, ku kituna Citarum kudu dibendung sing jadi talaga ngemplang, sayagikeun parahuna, mangka tohaga pikeun urang lalayaran, naha bisa Andika nyumponan eta pamenta?

Tapi samemeh balebat, boh parahu boh talaga, kudu anggeus kudu jadi, mun henteu bukti, andika nya kabeurangan, sing wayahnya, oleng panganten teu tulus, lalayaran dibedokeun (Sontani, 1962:45).

'Jauh dari mata dan telinga yang melihat dan mendengar, di tempat itulah hamba mau menyerah. Karena itu bendunglah Citarum sampai tercipta telaga luas; bikinkan juga perahu buat kita berdua berlayar di atasnya. Tapi telaga dan perahu mesti siap sebelum fajar besok menyingkap gelap; kesiangan berarti kegagalan, berarti tuan tidak bisa memenuhi, berarti pula perkawinan tidak jadi.'

Sang Kuriang menyanggupi syarat itu. Ia membendung Citarum dan membuat 
perahu dengan bantuan siluman. Ketika pekerjaan Sang Kuriang hampir selesai sesuai dengan waktu yang diminta, Dayang Sumbi membuat tipu daya seolah-olah waktu sudah pagi.

"Sang Kuriang! Sing wayahnya cape gawe teu kapake, oleng panganten teu tulus, lalayaran dibedokeun. Tuh, balebat geus marakbak, ciri wanci enggeus beurang, andika nya kabeurangan”.

"Wayah kieu geus balebat? Mustahil teu bisa jadi (nyepak parahu nepi ka nangkub), naha saha mangkelukna nu geus wani ngabobodo? Tuh ilikan nu marakbak! Di enyana geus balebat ku kasakten Dayang Sumbi. Aeh-aeh naha silo kabobodo ku panenjo? Balebat ti mana horeng? Kapan sakuriling bungking masih keneh poek mongkleng ciri wanci tengah peuting! Eta mah leuweung diburu! Bet $k u$ ngalalakian mangkeluk nu ngabohongna! Dayang Sumbi, curang teh bet kaleuleuwihan, ngaenyakeun ka nu lain, ngabobodo lakar daek, kawas ka nu rodek hulu! (Sontani, 1962:66)

'Itu perahu yang hampir selesai, akan terbengkalai tidak terpakai, berlayaran mesti diurungkan, perkawinan mesti dibatalkan. Lihat! Fajar di Timur sudah keluar, berarti tuan kesiangan, berarti semua janji telah tuan langgar'.

'Fajar sudah keluar? Mustahil! Tak bisa, siapa yang kurang ajar, berani membohongi? Hei para siluman lihat itu cahaya yang memancar! Kalaupun betul fajar keluar, disebabkan kemampuan Dayang Sumbi melebihi kemampuanku, mana janjimu akan memberi bantuan? Hei Dayang Sumbi, sia-sialah tuan membohongi menyebut fajar'.

Sang Kuriang adalah orang yang cerdas. Ia mengetahui bahwa balebat yang muncul adalah muslihat Dayang Sumbi karena sinar itu dalam pandangannya hanya muncul di sekitar lingkungannya, tempat ia membendung Citarum, sedangkan di tempat lain masih tampak gelap. Ia bersumpah serapah kepada Dayang Sumbi:
Sang Kuriang: Bet ku ngalalakianan, mangkeluk nu ngabohongnya! Dayang Sumbi! Curang teh bet kaleuleuwihan, ngaeunyakeun ka nu lain, ngabobodo lakar daek, kawas ka nu rodek hulu!

Dayang Sumbi: Sang Kuriang! Sing eling! Itu nu hibar marakbak, eta teh sidik balebat! Sang Kuriang: Lain! Hibar lain sahibarna. Hibar kersaning dewata, nitah eling geura nyaring, ngeureunan gawe tipeuting.

Sang Kuriang: Aeh bet teu kapalang ngabohong, abong letah teu tulangan! $\mathrm{Na}$ naon ari dewata, mun di dieu nyao teuing? Dayang Sumbi! Mangka waspada, yen mungguh keur kula: taya dewata, salian ti nya kula! (Sontani, 1962:66-67).

Sang Kuriang: Kurang ajar itu makhluk yang berani memperdayakan! Hei Dayang Sumbi! Sia-sia tuan membohongi menyebut fajar kepada sesuatu yang bukan fajar, sia-sialah tuan berbuat curang, mau mengabui mata orang!'

Dayang Sumbi: Percayalah, itu cahaya yang memancar adalah cahaya fajar

Sang Kuriang: Bukan!'

Dayang Sumbi: Itu cahaya yang memancar, demi kehendak dewata adalah cahaya fajar untukmu dan untukku' .

'Katakanlah kehendak dewata! Bualkanlah nama dewata, tapi apa arti dewata bagku, kalau aku tak pernah tahu atas kehendak siapa, aku ada di dunia? Bagiku tiada dewata melainkan aku!'

Oleh karena itu, Sang Kuriang sesumbar: Ku kituna, demi kula nu kawasa, ulah sambat kaniaya, bongan andika geus daek, wuri-wuri ngaheureuyan, ngabobodo nincak hulu, ayeuna daek teu daek rek dipaksa dipigarwa (Sontani, 1962:67). 'Maka demi kuasaku yang kutunduki; demi diriku yang tidak sudi dibohongi, sekali tuan menerima pinanganku, tuan sekarang mesti dan akan dipaksa jadi isteriku!'

Dayang Sumbi lari. Sang Kuriang mengejar. Dayang Sumbi mengambil kujang, mengancam bunuh diri jika Sang Kuriang mendekat. Sang Kuriang: mun andika teuas kitu, geus kersaning kula, 
sakali maju kula ge nya cadu mundur! (maju rek ngarebut kujang) (Sontani, 1962:69). Menepati perkataannya, Dayang Sumbi menusukkan kujang ke dalam jantungnya: Dayang Sumbi: Duh Agung! Kuring pasrah saayana. Sang Kuriang! Anaking, geura eling! (Sontani, 1962:69) 'Ya dewata! KepadaMu kuserahkan sukmaku, Sang Kuriang, anakku, aku adalah ibumu'. Dayang Sumbi mati membawa keyakinannya bahwa Sang Kuriang adalah benar-benar anaknya. Sang Kuriang pun kukuh dengan keyakinannya bahwa Dayang Sumbi bukanlah ibunya. Jika Dayang Sumbi bunuh diri demi membela keyakinannya, Sang Kuriang membalas tantangan itu dengan perbuatan yang sama. Ia mengambil putusan membunuh diri untuk membuktikan kemerdekaan hidupnya, sebagaimana terbaca dalam kutipan berikut.

Keur ngabela kayakinan, manehna geus wani nyokot putusan nu nangtang. Tinggal kula, ngajawab panantangna $k u$ putusan nu nganggeuskeun (nyokot kujang) Ku kituna, mun manehna geus wani nemahan pati alatan aya nu dipercaya, kula ayeuna rek nutup ieu lalakon, rek nutup ieu sakabeh, ku jalan ngeuweuhkeun maneh demi kawasa sorangan (Sontani, 1962:70). 'Untuk membela keyakinan, dia sudah berani mengambil putusan dengan bunuh diri. Tinggallah aku mengambil putusan terhadap adaku sendiri (mengambil kujang dari tangan mayat).'

Sang Kuriang mengambil nyawanya atas kuasa sendiri, tidak menyerahkannya pada kehendak dewata. Ia tidak meminta digaibkan oleh dewata sebagaimana kisah dalam mitosnya.

\section{PEN UTUP}

Mitos Sangkuriang telah teraktualisasikan dalam drama Sang Kuriang. Mitos produk masyarakat lampau itu memperoleh tanggapan masyarakat modern. Utuy T. Sontani dalam Sang Kuriang menampilkan sesuatu yang berbeda dengan mitosnya. Utuy dalam drama librettonya telah menghidupkan tokoh Sang Kuriang dan Dayang Sumbi serta menjiwainya dengan pikiran-pikiran dan paham baru. Sang Kuriang versi Utuy ini dapat dikatakan sebagai tafsir baru yang berbeda dengan mitosnya.

Beberapa hal baru yang terdapat dalam Sang Kuriang karya Utuy Tatang Sontani adalah struktur cerita berawal dari kegelisahan Sang Kuriang yang ingin mengetahui siapa ayahnya dan berakhir dengan bunuh dirinya Sang Kuriang. Yang paling menonjol struktur drama dua babak Sang Kuriang karya Utuy T. Sontani adalah Sang Kuriang yang berpikir kritis dalam menghadapi masalah. Segala sesuatu bisa diterima oleh dirinya apabila sesuatu itu sesuai dengan akal dan logika berpikirnya.

Kontrasnya nilai-nilai kepercayaan dengan logika berpikir. Masyarakat lama yang dalam hal ini diwakili Dayang Sumbi jika mengatakan sesuatu, orang lain memercayainya, sedangkan masyarakat baru atau generasi baru yang diwakili Sang Kuriang akan memercayai sesuatu yang dikatakan orang lain jika perkataannya sesuai dengan logika (masuk akal). Yang juga tidak kalah pentingnya adalah Sang Kuriang karya Utuy begitu mengusung individualitas dan kebebasan dalam berpikir dan bertindak.

\section{DAFTAR SUMBER}

Anonim. 1968.

"Sangkuriang teh Pieunteungeun Lain Turutaneun". Sipatahoenan, Tahun 1968 .

HT. Faruk. 2008. "Kisah Penjara Etis dan Filosofis: Analisis Lintas Budaya Atas Tembok Tidak Tinggi Karya A. Samad Ismail dan Mereka yang Dilumpuhkan Karya Pramoedya Ananta Tur dalam Jurnal Humaniora, Vol.20, No. 2 Juni 2008.

Kartini, Tini. 1982.

"Sastra Lakon dalam Bahasa Sunda". Jakarta: Proyek Penelitian Bahasa dan Sastra Indonesia dan Daerah Jawa Barat. 
Kompas. 1979.

"Utuy Tatang Sontani Meninggal di Moskwa Akibat Serangan Jantung". Kompas, 19 September 1979.

Oemaryati, Boen. 1971.

Bentuk Lakon dalam Sastra Indonesia. Jakarta: Gunung Agung.

Prajakusumah, A.S. 1981.

"Gending Karesmen". Jakarta:

Kumpulan Drama Konvensi

Tradisional.

Rampan, Korrie Layun.1980.

"In Memoriam Utuy T. Sontani. Warnasari Th II, No. 13

Rosidi, Ayip. 1979.

"Mengenang Utuy T. Sontani (19181979)". Sinar Harapan, Jumat, 5 Oktober 1979.

1966.

Kesusastraan Sunda Dewasa Ini. Jatiwangi: Cupumanik.

1989.

Beberlayar. Jakarta: Girimukti Pasaka.

Soewargana, Oejeng. 1977.

Gending Karesmen. Bandung: Ganaco.

Sutiasumarga, Rusman.

"Sangkuriang". dalam Pustaka dan Budaya, Th I, Nomor 3/I, September 1959.

Sontani, Utuy Tatang.

"Pikiran Sang Kuriang". Warga, 12 Februari 1957.

1962.

Sang Kuriang. Jakarta: Bharatara.

1954.

"Sang Kuriang Dayang Sumbi. Warga, Nomor 96, 97, 98 Taun ka IV, Mei 1954.

Toer, Prameodya Ananta. 1952.

"Berkenalan dengan Utuy T. Sontani". Nusa Suasana Th. I, 1 September 1952.

Wibisana, Wahyu. 1977.

"Sebuah Tinjauan mengenai KaidahKaidah Gending Karesmen dan Prospek

Perkembangannya". Bandung: UPI.
Zaidan, A. Rozak. 2005.

"Revolusi dalam Sastra Drama Selepas Kemerdekaan (Dasawarsa 1950-an)" dalam Revolusi, Nasionalisme, dan Banjir Roman. Jakarta: Pusat Bahasa. 